\title{
Analisis determinan produksi kopi di Kecamatan Kuala Betara Kabupaten Tanjung Jabung Barat
}

\author{
Deny Putra*; Zulgani ; Parmadi \\ Prodi Ekonomi Pembangunan Fak. Ekonomi dan Binsis Universitas Jambi \\ *E-mail korespodensi: denyputra00000@gmail.com
}

\begin{abstract}
This study aims to: 1) To determine and analyze coffee farmers' social and economic characteristics in Kuala Betara District, Tanjung Jabung Barat Regency. 2) To determine and analyze the effect of land area, capital, and labor on coffee production, Kuala Betara District, Tanjung Jabung Barat Regency by using multiple linear regression analysis tools. Based on the social and economic characteristics of Coffee Farmers in Kuala Betara District, Tanjung Jabung Barat Regency, it can be concluded that the average age of the Coffee Farmers is 39 years, the average number of dependents of Coffee Farmers is two dependents, the average working hours of Coffee Farmers is 3 hours, The average coffee production produced by coffee farmers is $57 \mathrm{~kg}$, the middle area of land owned by coffee farmers is 1.46 hectares, the average capital of coffee farmers is Rp. 187,400, the average workforce of Coffee Farmers is only one person, and the average income of the respondents is Rp. 1,710,000 per month. Based on the results of multiple linear regression, it can be concluded that partially only the variables of land area and labor have a significant effect on coffee production in Kuala Betara District, Tanjung Jabung Barat Regency.
\end{abstract}

Keywords: Land area, Capital, Labor, Production

\begin{abstract}
Abstrak
Penelitian ini bertujuan untuk: 1) Untuk mengetahui dan menganalisis karakteristik sosial dan ekonomi Petani Kopi di Kecamatan Kuala Betara Kabupaten Tanjung Jabung Barat. 2) Untuk mengetahui dan menganalisis pengaruh luas lahan, modal dan tenaga kerja terhadap produksi Kopi Kecamatan Kuala Betara Kabupaten Tanjung Jabung Barat dengan menggunakan alat analisis regresi linier berganda. Berdasarkan karakteritik sosial dan ekonomi Petani Kopi di Kecamatan Kuala Betara Kabupaten Tanjung Jabung Barat dapat disimpulkan rata-rata umur Petani Kopi yaitu 39 tahun, rata-rata jumlah tanggungan Petani Kopi sebanyak 2 orang tanggungan,rata-rata jam kerja Petani Kopi selama 3 jam, rata-rata produksi kopi yang dihasilkan Petani Kopi sebesar $57 \mathrm{~kg}$, rata-rata luas lahan yang dimiliki Petani Kopi sebesar 1,46 Ha, rata-rata modal Petani Kopi sebesar Rp. 187.400, rata-rata tenaga kerja Petani Kopi hanya sebanyak 1 orang dan rata-rata pendapatan responden sebesar Rp. 1.710 .000 perbulan. Berdasarkan hasil regresi linier berganda dapat disimpulkan bahwa secara parsial hanya variabel luas lahan dan tenaga kerja yang berpengaruh signifikan terhadap produksi Kopi di Kecamatan Kuala Betara Kabupaten Tanjung Jabung Barat.
\end{abstract}

Kata kunci: Luas lahan, Modal, Tenaga kerja, Produksi.

\section{PENDAHULUAN}

Pertanian merupakan salah satu sektor yang menjadi kunci dalam perekonomian Indonesia. Sektor pertanian dapat menyumbang pertumbuhan PDB Indonesia pada Triwulan II tahun 2018 sebesar 13,63. Sektor pertanian di Indonesia dibagi ke dalam lima subsektor yaitu tanaman pangan (lebih dikenal dengan pertanian rakyat), perkebunan, 
kehutanan, peternakan, dan perikanan. Subsektor perkebunan merupakan andalan bagi pendapatan nasional dan devisa negara Indonesia, yang dapat dilihat dari nilai ekspor komoditas perkebunan, pada Tahun 2015 total ekspor perkebunan mencapai US\$23,933 milyar atau setara dengan Rp. 311,138 triliun (asumsi 1 US\$=Rp.13.000).

Karakteristik tanaman dalam subsektor perkebunan dapat dikelompokkan menjadi dua, yaitu tanaman tahunan dan tanaman semusim. Tanaman tahunan merupakan tanaman yang membutuhkan waktu yang panjang untuk berproduksi. Jangka waktu produksi tanaman tahunan mampu mencapai puluhan tahun dan bisa dipanen lebih dari satu kali. Contoh tanaman tahunan misalnya kelapa, kelapa sawit, karet, kakao, cengkeh, pala, kemiri, cengkeh, kayu manis, panili, teh, kapuk, dan kopi. Salah satu komoditas unggulan dalam subsektor perkebunan adalah kopi.

Berdasarkan data dari International Coffee Organization (2017) Indonesia menempati posisi keempat sebagai negara penghasil kopi terbesar dari seluruh negara produsen kopi di dunia dengan total produksi sebesar 10 juta karung biji kopi. Hal tersebut menunjukkan bahwa Indonesia mempunyai potensi besar di komoditas kopi, bukan hanya sebagai produsen saja namun juga sebagai negara eksportir kopi terbesar keempat di dunia

Liberika menghasilkan biji kering sekitar 800-1.000 kg/ha. Sementara itu, menurut hasil pengujian Balai Penelitian Tanaman Industri dan Penyegar (Balittri), penambahan pembenah seperti kapur dan pupuk mikroba dapat meningkatkan produksi biji kering hingga $1.500 \mathrm{~kg} / \mathrm{ha}$.Biji kopi Liberika juga diekspor ke Malaysia dan Singapura dengan kisaran harga Rp25 ribu/kg, lebih tinggi dari Robusta yang dihargai Rp18 ribu/kg. Di tahun 2017 dan 2018, harganya bahkan sempat mencapai Rp45 ribu/kg.

Satu batang pohon kopi liberika bisa menghasilkan lebih kurang sekitar $15-20 \mathrm{~kg}$ buah kopi. Jika sudah mulai berbuah, dalam kondisi ideal kopi liberika meranti bisa dipanen 20 hari sekali. Biji kopi liberika kualitas bagus bisa dijual dengan harga Rp 90.000-120.000 per kg dan akan meningkat menjadi Rp 200.000 per kg ketika sudah disangrai. Jika sudah dalam bentuk bubuk harganya meningkat lagi menjadi $\mathrm{Rp} 250.000$ 270.000 per kg. Untuk kopi liberika luwak harganya cukup fantastis, yaitu Rp 600.000 untuk yang sudah disangrai dan Rp 1.100.000-1.300.000 per kg untuk yang sudah bubuk. Peningkatan harga kopi dalam setiap proses biji sampai menjadi bubuk disebabkan karena adanya penyusutan berat, dari buah kopi (ceri) sampai menjadi green bean menyusut hingga 50-60\%. Dan setelah disangrai menyusut lagi sekitar 10-15\% (Indonesia Investment, 2018).

Umur 2 tahun pohon kopi liberika (buah pasir) dan buah pertama harus dibuang. Kopi liberika akan siap dipanen ketika berumur 2,5-3 tahun. Panen raya terjadi dalam 45 bulan dengan interval pemetikan 2 minggu sekali pada pohon yang sama. Jam kerja petani kopi liberika dalam sehari yaitu 3 sampai 5 jam dan biaya upah tenaga kerja yang dikeluarkan selama satu hari kerja yaitu Rp. 50.000 - Rp. 70.000. Lebih dari 90\% dari total perkebunan dibudidayakan oleh petani skala kecil yang memiliki lahan sekitar 1-2 hektar. Hal ini berdampak pada sulitnya menjaga kestabilan volume dan kualitas produksi sehingga daya saingnya di pasar internasional kurang kuat (Indonesia Investment, 2018).

Provinsi Jambi merupakan salah satu Provinsi di Indonesia yang banyak mengusahakan tanaman perkebunan baik berupa perkebunan rakyat maupun perkebunan besar negara ataupun besar swasta. Banyaknya yang mengusahakan sektor perkebunan dapat dilihat dari sumbangsih pada PDRB yaitu sebesar $29 \%$. Terdapat lima tanaman perkebunan unggulan di Provinsi Jambi yaitu karet, kelapa sawit, kelapa dalam, cassiavera dan kopi (Dinas Perkebunan Provinsi Jambi 2015).

Kabupaten Tanjung Jabung Barat merupakan salah satu Kabupaten yang terdapat di Provinsi Jambi yang menghasilkan tanaman perkebunan diantaranya adalah tanaman kelapa sawit dan kelapa dalam. Bukan hanya dikenal sebagai daerah penghasil kelapa sawit dan kelapa dalam, Kabupaten Tanjung Jabung Barat belakangan ini juga dikenal 
sebagai salah satu daerah penghasil kopi yang terbukti dengan menempati posisi produksi terbesar ketiga setelah Kabupaten Merangin dan Kabupaten Kerinci di Provinsi Jambi.

Saat ini kopi liberika banyak dikembangkan pada lahan-lahan gambut yang tidak mungkin ditanami kopi jenis lain, diantaranya berkembang di wilayah Tanjung Jabung Barat. Produksi kopi liberika asal Tanjung Jabung Barat memiliki pasar yang baik di Malaysia dengan harga jual lebih tinggi sehingga kopi liberika menjadi salah satu sumber pendapatan bagi sebagian masyarakat Tanjung Jabung Barat. Kopi Liberika memiliki pasar dan harga jual yang tinggi, beberapa tahun terakhir ini telah terjadi peningkatan luas lahan kopi di Tanjung Jabung Barat. Bertambahnya luas lahan kopi ini mengindikasikan telah terjadi peningkatan minat petani yang ingin mengusahakan kopi. Berdasarkan data dari Dinas Perkebunan Provinsi menunjukan bahwa hampir setiap tahun terjadi peningkatan luas lahan kopi.

Kecamatan Kuala Betara merupakan bagian dari Kabupaten Tanjung Jabung Barat yang menjadi penghasil kopi liberika terbesar di kabupaten ini. Kopi liberika menjadi salah satu sumber pendapatan masyarakat di Kecamatan Kuala Betara. Kecamatan Kuala Betara telah mempunyai agroindustri kopi yang mampu meningkatkan perekonomian dan pendapatan petani. Penerimaan usahatani kopi liberika di Kecamatan Kuala Betara sebesar Rp. 17.084.250/hektar/tahun dan total biaya produksi yang dikeluarkan petani sebesar Rp. 6.956.724,38/hektar. Oleh karena itu, pendapatan usahatani Kopi liberika di Kecamatan Kuala Betara sebesar Rp. 10.127.525,63/hektar/tahun. Pendapatan usahatani diperoleh melalui pertimbangan sebagai berikut, luas lahan kopi rata-rata 2,67 hektar, produksi rata-rata usahatani sebesar $569,475 \mathrm{~kg} / \mathrm{hektar} / \mathrm{tahun}$ dan harga kopi Rp. 30.000/kg.

Kopi sebagai komoditas pertanian seringkali mengalami fluktuasi harga, disebabkan ketidakseimbangan permintaan dan persediaan komoditas. Walaupun kopi liberika memberikan sumbangan terhadap perekonomian petani, namun dengan adanya kendala dan perubahan harga, akankah usahatani kopi masih mampu memenuhi kebutuhan ekonomi keluarga di masa mendatang. Panjangnya waktu produksi dan faktor produksi menjadi penentu pencapaian produksi kopi liberika. Upaya peningkatan pendapatan dan kesejahteraan petani dihadapkan pada permasalahan pengetahuan petani yang rendah, keterbatasan modal, luas lahan yang sempit, kurangnya keterampilan petani dan kondisi alam yang sangat menentukan hasil produksi kopi liberika di Kecamatan Kuala Betara.

Salah satu faktor yang dapat menentukan besarnya pendapatan adalah luas lahan. Menurut KBBI yeang dimaksud dengan lahan adalah tanah terbuka atau tanah garapan. Jadi, kesimpulannya bahwa lahan adalah suatu tanah yang digunakan untuk pertanian yang memiliki jumlah tertentu. Selanjutnya luas lahan pertanian ini akan mempengaruhi efisien atau tidaknya usaha pertanian yang dilakukan. Rahim (2007) mengatakan bahwa semakin luas lahan (yang digarap/ditanami), semakin besar jumlah produksi yang dihasilkan oleh lahan tersebut.

Menurut Nougroho (2010) areal pertanian khususnya lahan pertanian secara garis besar mendatangkan dua jenis manfaat yaitu: pertama, manfaat atas penggunaan yang ada (uses values), manfaat ini dihasilkan dari eksploitasi atau kegiatan usahatani di lahan pertanian. Uses Values terdiri dari dua jenis yaitu, manfaat langsung dan manfaat tidak langsung. Manfaat langsung ditandai oleh produk yang terukur secara riil dan dapat ditransaksikan dalam bentuk harga (marketable output) serta berfungsi sebagai sumber pendapatan masyarakat, dan manfaat yang tidak terukur dengan uang (unpriced benefit) namun secara langsung dapat dirasakan masyarakat seperti fungsi ketahanan pangan. Manfaat kedua adalah manfaat bawaan, manfaat ini timbul dengan sendirinya seiring aktifitas usahatani, kemungkinan manfaat ini baru dapat dirasakan di masa datang bukan saat ini, seperti keanekaragaman hayati (biodiversity). 
Lahan pertanian membawa manfaat tidak langsung berkaitan dengan aspek lingkungan hidup. Manfaat ini terdiri atas: mencegah terjadinya banjir (flood mitigation); pengendali keseimbangan tata air (water resource conservation); pengurai limbah organik (organic waste disposal); mencegah erosi (erosion reduction); mencegah pencemaran/panas udara (heat mitigation) dan tentu saja suasana lingkungan khas perdesaan (rural amenity). Manfaat lahan pertanian yang berkaitan dengan aspek lingkungan hidup ini selanjutnya dikenal sebagai multifungsi lahan.

Tanah merupakan faktor produksi yang mempunyai kedudukan paling penting disamping ketiga faktor produksi yang lainnya. Maksudnya adalah tanpa faktor produksi tanah maka usahatani tidak dapat dilakukan, dimana usaha akan dilakukan atau dimana tanaman akan ditanam apabila tidak ada tanah. Dengan kata lain, tanah merupakan tempat dimana proses produksi berjalan dan dari mana hasil produksi dikeluarkan (Mubyarto 1995). Luas tanam merupakan ukuran potensi ekonomi petani untuk mengelola usahataninya. Petani dengan tanah yang luas akan menghasilkan tingkat produksi yang tinggi, karena menurut Mubyarto (1995) menjelaskan bahwa luas pemilikan lahan mempunyai hubungan yang positif dengan besarnya produksi. Semakin luas pemilikan lahan, semakin besar produksi yag dihasilkan.

Menurut Karyanto (2008) Modal merupakan faktor yang menentukan besarnya produksi. Kurangnya modal dalam usaha tani akan menyebabkan penggunaan sarana produksi menjadi sangat terbatas yang pada gilirannya akan mempengaruhi pendapatan. Menurut Firdaus (2012) mendefenisikan modal merupakan uang yang digunakan untuk membeli harta seperti mesin, peralatan, piutang usaha tenaga kerja dan bahan mentah.

Dalam pengembangan suatu usaha untuk meningkatkan produksi maka memerlukan tenaga kerja yang handal, karena tenaga kerja merupakan faktor produksi yang mengelola input menjadi output. Tenaga kerja adalah sumber yang berupa jasa-jasa manusia baik itu fisik maaupun mental. Dengan demikian tenagga kerja bukan saja di artikan sabagai tenaga kerja jasmani yang digunakan dalam proses produksi,akan tetapi jaga meliputi kemampuan tenaga kerja, ketrampilan kerja maupun pengetahuan yang terdapat dalam diri pekerja. Secara teoritis, tenaga kerja memiliki konstribusi positif terhadap peningkatan produksi, terutama tenagga kerja yang memiliki skill yang baik (Harahap, 2016).

Penurunan produksi dan produktivitas dapat disebabkan oleh faktor langsung berupa faktor produksi yang digunakan. Faktor produksi yang dimaksud antara lain luas lahan, tenaga kerja dan modal. Pola perkebunan yang masih bersifat tradisional menyebabkan rendahnya pengetahuan petani. Rendahnya pengetahuan petani membuat penggunaan faktor produksi masih didasarkan pada pengetahuan petani itu sendiri. Pengorganisasian mengenai sumberdaya berupa input-input dan sarana produksi yang digunakan akan sangat berguna bagi pencapaian efisiensi usaha dan waktu. Pengorganisasian tersebut terutama menyangkut bagaimana mengalokasikan berbagai input dan fasilitas yang akan digunakan dalam proses produksi sehingga proses produksi dapat berjalan secara efektif dan efisien. Selain faktor langsung terdapat faktor tidak langsung yaitu faktor sosial ekonomi petani. Faktor sosial ekonomi mencakup umur petani, jam kerja, pengalaman berusahatani, dan tingkat pendidikan. Setiap petani memiliki karakteristik sosial ekonomi yang berbeda-beda. Karakteristik sosial ekonomi petani akan mempengaruhi pola pikir dari setiap petani. Perbedaan ini akan menimbulkan perbedaan cara petani dalam mengelola usahataninya sehingga mempengaruhi produksi dan produktivitas dari usahataninya.

Sebagaimana menurut Haryanto (2007) agar suatu usahatani tidak rugi maka harus diketahui lebih dahulu analisis usahataninya, hal-hal yang perlu di ketahui antara lain beberapa modal yang dibutuhkan, beberapa titik nilai impas dan beberapa nilai perbandingan antara penerimaan dengan biaya. Selanjutnya menurut Pitojo,(2005) analisis usaha tani merupakan gambaran yang perlu dicermati manakala akan melakukan 
usahatani, serta juga ditegaskan bahwa data usahatani bersifat situasional dan kedaerahan karena dipengaruhi input produksi, tenaga kerja setempat dan hasil serta harga yang berlaku. Suratiyah, (2006) juga menyatakan bahwa dengan memahami data-data usaha tani maka petani dapat merencanakan produksi sesuai dengan pendapatan yang diinginkan.

Keseluruhan unsur-unsur dalam elemen input tadi selanjutnya dengan menggunakan teknik-teknik atau cara-cara tertentu, diolah atau diproses sedemikian rupa untuk menghasilkan sejumlah output tertentu. Teori produksi akan membahas bagaimana penggunaan input untuk menghasilkan sejumlah output tertentu. Menurut Aziz (2003), teori produksi dapat dibedakan menjadi dua bagian yaitu yang pertama, teori produksi jangka pendek dimana apabila seseorang produsen menggunakan faktor produksi maka ada yang bersifat variabel dan yang bersifat tetap. Kedua, teori produksi jangka panjang apabila semua input yang digunakan adalah input variabel dan tidak terdapat input tetap, sehingga dapat diasumsikan bahwa ada jenis faktor produksi yaitu tenaga kerja (TK).

Berdasarkan hasil observasi yang peneliti lakukan bahwa Petani Kopi di Kecamatan Kuala Betara Kabupaten Tanjung Jabung Barat memiliki lahan perkebunan kopi seluas 0,8 Ha sampai 3,5 Ha. Kemudian modal yang petani keluarkan untuk produksi kopi dimulai dari Rp. 130.000 sampai Rp. 310.000. Untuk tenaga kerja yang digunakan petani sebagai faktor produksi yaitu 1 sampai 4 orang. Sedangkan dari luas lahan, modal dan tenaga kerja yang dimiliki atau digunakan petani sebagai faktor produksi, petani memproduksi kopi dari sebanyak $35 \mathrm{~kg}$ sampai $130 \mathrm{Kg}$ perbulannya. Berdasarkan data tersebut menunjukkan bahwa secara umum semakin besar luas lahan, modal dan tenaga kerja maka produksi juga akan meningkat. Namun tidak seluruh petani yang memiliki luas lahan, modal dan tenaga kerja yang besar namun produksinya juga lebih besar dibanding petani yang memiliki luas lahan, modal dan tenaga kerja lebih kecil. Untuk itu maka perlu dilakukan penelitian dengan judul "Analisis determinan produksi kopi di Kecamatan Kuala Betara Kabupaten Tanjung Jabung Barat”.

\section{METODE}

\section{Metode analisis data}

Metode penelitian dalam penelitian ini menggunakan analisis regresi linear berganda dalam bentuk persamaan yaitu sebagai berikut (Sugiyono, 2012):

$$
\log Y=\alpha+\beta_{1} X_{1}+\beta_{2} X_{2}+\beta_{3} X_{3}+e
$$

Selanjutnya disederhanakan menjadi :

$$
\operatorname{LogPP}=\alpha+\beta_{1} L L+\beta_{2} M D+\beta_{3} T K+e
$$

Keterangan :

$\mathrm{PP} \quad=$ Pendapatan petani

A $=$ Konstanta

LL = Luas lahan

MD = Modal

TK = Tenaga kerja

$\beta=$ Koefisien regresi

e $=$ Error

\section{HASIL DAN PEMBAHASAN}

\section{Karakteristik umur petani kopi}

Jumlah Petani Kopi paling banyak berdasarkan tingkatan umur yaitu pada kelompok umur 40-46 tahun dengan jumlah Petani Kopi sebanyak 18 orang dengan 
proporsi sebesar 36 persen. Sedangkan jumlah Petani Kopi paling sedikit berdasarkan tingkatan umur yaitu pada kelompok umur 54-60 tahun dengan jumlah Petani Kopi sebanyak 2 orang dengan proporsi sebesar 4 persen. Berdasarkan hasil tersebut, dapat dikatakan bahwa rata-rata umur Petani Kopi yaitu 39 tahun, di umur ini dapat dikatakan sangat efektif dan efisien untuk mencari penghasilan dan dimana pada masa ini seseorang telah mempunyai banyak pengalaman sehingga dapat mengatasi masalah-masalah yang muncul.

\section{Karakteristik petani kopi berdasarkan jumlah tanggungan}

Jumlah tanggungan dengan jumlah Petani Kopi terbanyak yaitu 35 orang pada kelompok jumlah tanggungan 2-3 orang dengan proporsi 70 persen. Sedangkan jumlah Petani Kopi paling sedikit yaitu 7 orang pada kelompok jumlah tanggungan 4-5 orang dengan proporsi sebesar 14 persen. Berdasarkan hasil tersebut, dapat dikatakan bahwa rata-rata jumlah tanggungan Petani Kopi sebanyak 2 orang tanggungan. Besarnya jumlah tanggungan akan meningkatkan motivasi Petani Kopi untuk meningkatkan pendapatannya.

\section{Karakteristik petani kopi berdasarkan jam kerja}

Jam kerja dengan jumlah Petani Kopi terbanyak yaitu 37 orang dengan jam kerja selama 3 jam dengan proporsi 74 persen. Sedangkan jumlah Petani Kopi paling sedikit yaitu 4 orang pada jumlah jam kerja 5 jam dengan proporsi sebesar 8 persen. Berdasarkan hasil tersebut, dapat dikatakan bahwa rata-rata jam kerja Petani Kopi selama 3 jam.

\section{Karakteristik petani kopi berdasarkan produksi}

Produksi kopi dengan jumlah Petani Kopi terbanyak yaitu 35 orang dengan kelompok produksi kopi antara 35 - $54 \mathrm{~kg}$ dengan proporsi 70 persen. Sedangkan jumlah Petani Kopi paling sedikit yaitu 1 orang pada kelompok jumlah produksi antara 93 - 111 $\mathrm{kg}$ dengan proporsi sebesar 2 persen. Berdasarkan hasil tersebut, dapat dikatakan bahwa rata-rata produksi kopi yang dihasilkan Petani Kopi sebesar $57 \mathrm{~kg}$.

\section{Karakteristik petani kopi berdasarkan luas lahan}

Luas lahan dengan jumlah Petani Kopi terbanyak yaitu 30 orang yang berbeda pada kelompok luas lahan antara 0,7 sampai $1.2 \mathrm{Ha}$ dengan proporsi 60 persen. Sedangkan jumlah Petani Kopi paling sedikit yaitu 1 orang pada kelompok luas lahan antara 2,5 - 3 Ha dengan proporsi sebesar 2 persen. Berdasarkan hasil tersebut, dapat dikatakan bahwa rata-rata luas lahan yang dimiliki Petani Kopi sebesar 1,46 Ha.

\section{Karakteristik petani kopi berdasarkan modal}

Modal dengan jumlah Petani Kopi terbanyak yaitu 35 orang (70\%) pada kelompok modal antara Rp 130.000 - 190.000. Sedangkan jumlah Petani Kopi paling sedikit yaitu 1 orang $(2 \%)$ pada kelompok modal antara Rp. 260.000 - 310.000. Berdasarkan hasil tersebut, dapat dikatakan bahwa rata-rata modal Petani Kopi sebesar Rp. 187.400.

\section{Karakteristik petani kopi berdasarkan tenaga kerja}

Tenaga kerja dengan jumlah Petani Kopi terbanyak yaitu 34 orang dengan 1 orang tenaga kerja (68\%). Sedangkan jumlah Petani Kopi paling sedikit yaitu 2 orang dengan 4 
orang tenaga kerja sebayak 4 orang (4\%). Berdasarkan hasil tersebut, dapat dikatakan bahwa rata-rata tenaga kerja Petani Kopi hanya sebanyak 1 orang.

\section{Karakteristik petani kopi berdasarkan pendapatan}

Pendapatan dengan jumlah responden yang berada pada kelompok pendapatan sebesar Rp. 1.050.000 - Rp. 1.762.500 sebanyak 35 orang atau 70 persen. Sedangkan 2 orang (4\%) pada kelompok pendapatan sebesar Rp. 3.187.500 - 3.900.000 adalah yang sedikit jumlah petaninya. Berdasarkan hasil tersebut, dapat dikatakan bahwa rata-rata pendapatan responden sebesar Rp. 1.710.000.

\section{Analisis pengaruh luas lahan, modal dan tenaga kerja terhadap produksi kopi di Kecamatan Kuala Betara Kabupaten Tanjung Jabung Barat}

Berdasarkan hasil olahan data dengan menggunakan program SPSS versi 21 maka dapat diperoleh hasil regresi linier berganda yaitu pada Tabel 1

Tabel 1. Hasil perhitungan regresi linier berganda

\begin{tabular}{|c|c|c|c|c|c|c|c|}
\hline \multirow[t]{2}{*}{ Model } & \multicolumn{2}{|c|}{$\begin{array}{l}\text { Unstandardized } \\
\text { Coefficients }\end{array}$} & \multirow{2}{*}{$\begin{array}{c}\text { Coefficients }^{\mathrm{a}} \\
\begin{array}{c}\text { Standardized } \\
\text { Coefficients }\end{array} \\
\text { Beta }\end{array}$} & \multirow[t]{2}{*}{$\mathbf{t}$} & \multirow[t]{2}{*}{ Sig. } & \multicolumn{2}{|c|}{ Collinearity Statistics } \\
\hline & B & Std. Error & & & & Tolerance & VIF \\
\hline (Constant) & 13,770 & 5,594 & & 2,462 & ,018 & & \\
\hline $\mathrm{X} 1$ & 17,358 & 2,551 &, 514 & 6,805 &, 000 & , 144 & 6,926 \\
\hline $\mathrm{X} 2$ & $-2,178 \mathrm{E}-5$ &, 000 &,- 028 &,- 544 &, 589 & ,306 & 3,266 \\
\hline $\mathrm{X} 3$ & 14,006 & 1,716 &, 518 & 8,162 &, 000 & ,205 & 4,885 \\
\hline R Square & ,962 & & & & & & \\
\hline $\mathrm{F}$ tes & 389,038 & & & & & & \\
\hline F sig & 0,000 & & & & & & \\
\hline
\end{tabular}

\section{Koefisien determinasi $\left(\mathbf{R}^{2}\right)$}

Tabel 1 diatas dapat dilihat model summary diketahui nilai $\mathbf{R}_{\text {square }}$ sebesar 0,962 . Artinya sebesar 96,2 persen variasi produksi kopi oleh petani kopi dijelaskan oleh variabel dalam penelitian ini, sedangkan sisanya 3,8 persen dijelaskan oleh variabel lain diluar penelitian.

\section{Pengujian hipotesis secara simultan (Uji F)}

Uji F dilakukan untuk melihat pengaruh variabel independen secara simultan terhadap variabel dependen atau sering disebut uji kelinieran persamaan regresi. Pada tabel Anova diperoleh nilai sig 0,000 lebih kecil dari 0,05 ini berarti variabel independen luas lahan, modal dan tenaga kerja secara bersama-sama berpengaruh signifikan terhadap variabel dependen produksi petani kopi. Berpengaruhnya variabel bebas secara bersamasama terhadap produksi petani kopi dikarenakan luas lahan, modal dan tenaga kerja merupakan bagian dari faktor produksi.

\section{Pengujian hipotesis secara parsial (uji t)}

Uji t dilakukan untuk mengetahui apakah secara individu (parsial) variabel independen mempengaruhi variabel dependen secara signifikan atau tidak. Jika tingkat 
signifikansinya dibawah 5\% maka secara parsial luas lahan, modal dan tenaga kerja berpengaruh signifikan terhadap variabel dependen produksi petani kopi.

\section{Variabel luas lahan}

Dari hasil pengujian diperoleh nilai probabilita untuk variabel luas lahan sebesar 0,000 dengan tingkat keyakinan $(\alpha=5 \%)$ dapat dilihat bahwa nilai probabilita lebih kecil dari $0,05(0,000<0,05)$, artinya Ho ditolak dan Ha diterima artinya luas lahan berpengaruh signifikan terhadap produksi petani kopi. Dengan demikian hipotesis yang menyatakan pengaruh luas lahan terhadap produksi petani kopi benar dan terbukti.

\section{Variabel modal}

Dari hasil pengujian diperoleh nilai probabilita untuk variabel modal sebesar 0,589 dengan tingkat keyakinan $(\alpha=5 \%)$ dapat dilihat bahwa nilai probabilita lebih besar dari $0,05(0,589>0,05)$, artinya Ho diterima dan Ha ditolak artinya modal tidak berpengaruh signifikan terhadap produksi petani kopi. Dengan demikian hipotesis yang menyatakan pengaruh modal terhadap produksi petani kopi tidak benar dan tidak terbukti.

\section{Variabel tenaga kerja}

Dari hasil pengujian diperoleh nilai probabilita untuk variabel tenaga kerja sebesar 0,000 dengan tingkat keyakinan $(\alpha=5 \%)$ dapat dilihat bahwa nilai probabilita lebih kecil dari $0,05(0,000<0,05)$, artinya Ho ditolak dan Ha diterima artinya tenaga kerja berpengaruh signifikan terhadap produksi petani kopi. Dengan demikian hipotesis yang menyatakan pengaruh tenaga kerja terhadap produksi petani kopi benar dan terbukti.

\section{Analisis ekonomi}

\section{Pengaruh luas lahan terhadap produksi}

Dari hasil pengujian diperoleh bahwa luas lahan berpengaruh signifikan terhadap produksi petani kopi. Hasil ini sependapat dengan teori yang dikemukakan oleh Mubyarto (1995) yang mengatakan jika luas lahan meningkat maka produksi petani tambak akan meningkat, demikian juga sebaliknya. Sehingga hubungan antara luas lahan dengan produksi saling keterkaitan. Berpengaruhnya luas lahan terhadap produksi dikarenakan luas lahan kopi merupakan faktor yang paling penting untuk meningkatkan produksi kopi, tanpa ada lahan kopi maka kopi tidak dapat di produksi. Lahan yang sempit juga dapat menyebabkan produksi yang dihasilkan kecil.

\section{Pengaruh modal terhadap produksi}

Modal tidak berpengaruh signifikan terhadap produksi petani kopi. Hasil ini tidak sependapat dengan teori yang dikemukakan oleh Karyanto (2008) Modal merupakan faktor yang menentukan besarnya produksi. Kurangnya modal dalam usaha tani akan menyebabkan penggunaan sarana produksi menjadi sangat terbatas yang pada gilirannya akan mempengaruhi pendapatan.

Tidak berpengaruhnya modal kerja terhadap produksi kopi dikarenakan modal yang dipergunakan tidak begitu besar, walaupun modal ditingkatkan namun produksi yang dihasilkan tidak meningkat dengan signifikan. Malah sebaliknya, petani kopi dapat menghemat pengeluaran namun tetap dapat produksi seperti sebelumnya.

\section{Pengaruh tenaga kerja terhadap produksi}

Tenaga kerja berpengaruh signifikan terhadap produksi petani kopi. Hasil ini sependapat dengan penelitian yang dilakukan oleh Karyanto (2008) menemukan bahwa 
jumlah tenaga kerja dapat meningkatkan jumlah produksi. Berpengaruhnya antara tenaga kerja terhadap produksi karena petani kopi membutuhkan tenaga kerja untuk membantunya saat memanen kopi. Tanpa adanya tenaga kerja maka produksi sangat lambat dan tidak mampu untuk memenuhi permintaan konsumen.

\section{Implikasi penelitian}

Petani dalam peningkatan produksi kopi yaitu memperluas lahan agar waktu dan biaya produksi yang digunakan lebih efektif dan efisien. Lahan yang sempit akan membutuhkan waktu yang lama untuk jumlah produksi yang besar, namun dengan memperluas lahan, petani akan mempersingkat lama waktu produksi untuk jumlah produksi yang besar begitu juga pada biaya produksi sperti upah tenaga kerja akan lebih efisien. Petani kopi harus dibekali ilmu dalam pengelolaan usaha dan keuangan serta pelatihan tenaga kerja, hal ini agar usaha tani kopi dapat terus berjalan dengan lancar karena pengelolaan modal dilakukan dengan baik, serta kualitas tenaga kerja dalam pembibitan, pemupukan dan proses panen kopi dapat lebih baik.

\section{KESIMPULAN DAN SARAN}

\section{Kesimpulan}

Berdasarkan karakteritik sosial dan ekonomi Petani Kopi di Kecamatan Kuala Betara Kabupaten Tanjung Jabung Barat dapat disimpulkan rata-rata umur Petani Kopi yaitu 39 tahun, rata-rata jumlah tanggungan Petani Kopi sebanyak 2 orang tanggungan,rata-rata jam kerja Petani Kopi selama 3 jam, rata-rata produksi kopi yang dihasilkan Petani Kopi sebesar $57 \mathrm{~kg}$, rata-rata luas lahan yang dimiliki Petani Kopi sebesar 1,46 Ha, rata-rata modal Petani Kopi sebesar Rp. 187.400, rata-rata tenaga kerja Petani Kopi hanya sebanyak 1 orang dan rata-rata pendapatan responden sebesar Rp. 1.710.000 perbulan. Berdasarkan hasil regresi linier berganda dapat disimpulkan bahwa secara parsial hanya variabel luas lahan dan tenaga kerja yang berpengaruh signifikan terhadap produksi Kopi di Kecamatan Kuala Betara Kabupaten Tanjung Jabung Barat.

\section{Saran}

Rata-rata pendapatan petani kopi di Kecamatan Kuala Betara Kabupaten Tanjung Jabung Barat tidak besar, sehingga harus ditingkatkan lagi dengan peningkatan produksi yang dihasilkan perbulannya. Petani kopi di Kecamatan Kuala Betara Kabupaten Tanjung Jabung Barat agar dapat meningkatkan produksinya agar dapat memperluas luas lahan atau luas kolam serta memaksimalkan tenaga kerja untul lebih produktif.

\section{DAFTAR PUSTAKA}

Aziz, N. (2003). Pengantar mikro ekonomi. Bayumedia: Malang Firdaus, Ahmad. (2012). Akuntansi biaya. Edisi 3. Salemba Empat: Jakarta

Harahap, F., Silveira, S., \& Khatiwada, D. (2016). Land allocation to meet sectoral goals in Indonesia-An analysis of policy coherence. Journal Land Use Policy, 6 (1) $451-465$

Hastuti.D., A Delis., \& R Rosmeli. (2018). Pengembangan komoditas kelapa sawit dan karet serta dampaknya terhadap pendapatan petani di Kecamatan Pelepat Ilir, Jurnal Sains Sosio Humaniora, 2 (2), 92-104 
Indonesia Investment. (2018). Produksi domestik, ekspor dan konsumsi kopi indonesia. https://www.indonesia-investments.com/id/bisnis/komoditas/ kopi/item186? Date accessed: 16 February2019

International Coffee Organization, (2017). World coffee production. http://www.ico.org/prices/poproduction.pdf diakses pada 03 Maret 2021.

Junaidi.J., A Amril., Edi. J.K., M Ridwansyah., Hastuti.D., \& Aminah.S. (2019). Arahan zonasi pada pengembangan agrowisata berbasis community based tourism Desa Renah Alai, Jurnal Inovasi, Teknologi dan Dharma Bagi Masyarakat, 1 (1), 29-36

Karyanto, (2008). Peluang kerja dan berusaha di pedesaan. Jurnal Ekonomi Pembangunan. 5 (2) 149-152

Mubyarto, (1995). Pengantar ekonomi pertanian. lembaga penelitian, penyelidikan dan penerangan ekonomi dan sosial: Jakarta.

Nougroho, Dwi. (2010). Analisis kesediaan menilai hak pengembangan lahan sebagai dasar nilai program konservasi lahan persawahan di Kec. Moyudan Kab. Sleman. Thesis. Universitas Gadjah Mada: Yogyakarta

Rahim, Hastuti, R.R.D. (2007). Ekonomika pertanian, pengantar teori dan kasus. Penebar Swadaya: Jakarta

Rosmeli.R., \& D Hastuti. (2019). Determinan produksi perkebunan karet di Desa Purwasari Kabupaten Bungo, Jurnal Paradigma Ekonomika, 14 (2), 66-76

Suratiyah, (2008). Ilmu usahatani. Penebar Swadaya: Jakarta 